\title{
TIME-VARIANT MODEL OF HEAT-AND-MASS EXCHANGE FOR STEAM HUMIDIFIER
}

\author{
Igor Golinko ${ }^{1}$, Volodymyr Drevetskiy ${ }^{2}$ \\ ${ }^{1}$ National Technical University of Ukraine "Igor Sikorsky Kyiv Polytechnic Institute", Department of Automation of Heat and Power Engineering Processes, Kiev, Ukraine, \\ ${ }^{2}$ National University of Water Management and Nature Resources Use, Department of Automation, Electrical and Computer-Integrated Technologies, Rivne, Ukraine
}

\begin{abstract}
The dynamical model of heat-mass exchange for a steam humidifier with lumped parameters, which can be used for synthesis of control systems by inflowing-exhaust ventilation installations, or industrial complexes of artificial microclimate, is considered. A mathematical description that represents the dynamical properties of a steam humidifier concerning the main channels of control and perturbation is presented. Numerical simulation of transient processes for the VEZA KCKP-20 humidification chamber to the influence channels was carried out. The achieved dynamical model of a humidification chamber can be the basis for the synthesis of automatic control systems and simulation of transient states. A significant advantage of the obtained mathematical model in the state space is the possibility of synthesis and analysis of a multidimensional control system.
\end{abstract}

Keywords: dynamical model, state space, steam humidifier

\section{NIESTACJONARNY MODEL WYMIANY CIEPLA I MASY DLA NAWILŻACZA PAROWEGO}

\begin{abstract}
Streszczenie. Rozważono model dynamiczny wymiany ciepła i masy nawilżacza parowego o parametrach skupionych, który można zastosować do syntezy układów sterowania przez instalacje wentylacyjne nadmuchowo-wywiewne lub przemystowe kompleksy sztucznego mikroklimatu. Przedstawiono opis matematyczny przedstawiajacy właściwości dynamiczne nawilżacza parowego dotyczace głównych kanatów regulacji $i$ zaburzeń. Przeprowadzono symulację numeryczna procesów przejściowych dla komory nawiliajacej VEZA KCKP-20 z kanałami wphywowymi. Powstały model dynamiczny komory nawilżania może być podstawa do syntezy automatycznych układów sterowania i symulacji stanów nieustalonych. Istotna zaleta uzyskanego modelu matematycznego w przestrzeni stanu jest możliwość syntezy i analizy wielowymiarowego układu sterowania.
\end{abstract}

Slowa kluczowe: model dynamiczny, przestrzeń stanu, nawilżacz parowy

\section{Introduction}

When heating the buildings, water and air systems are most often used. Air heating systems are used recently and have proven themselves as high-speed, with a small specific capital cost. Air heating systems use electric heaters with a distributed automatic control system [11]. For air heating of commercial and business centres, warehouses and industrial buildings, centralized ventilation and conditioning systems are used. The achievement of high performance indicators of industrial conditioning systems involves the development of adequate mathematical models of climatic equipment and their control methods.

Steam humidifying cameras have been widely used in air conditioning. Thanks to technological features, steam humidification is indispensable for creating artificial microclimate: in operating rooms; in the technology of manufacturing drugs, or semiconductor materials of the electronic industry, and so on. In contrast to the spray-type humidification chambers (the process of adiabatic or polytrophic humidification), in the case of steam humidification (the process of isothermal humidification) there is no need for additional heating of air after moisture [1].

In developing a mathematical model, the task is to determine the limits of its detalization. The dynamical model should be simple for its research and synthesis of the control system, and also take into account the features of heat-mass ex-change. Researchers use mathematical models with lumped [4, 12] and distributed $[5,6]$ parameters to simulate the dynamical processes of heat-mass exchange equipment. Models with lumped parameters are simpler in the calculations and make it possible to obtain an analytical solution. Models with distributed parameters apply for more exact mathematical description. An analytical modelling of equipment with distributed parameters is a rather complicated task, transcendental functions appear in the solution [5]. For such tasks numerical methods of the solution are used in practice.

\section{Using dynamic models}

Typically, static models of process equipment are used to design and calculate the power of a particular plant. Dynamic models of process equipment are used for the synthesis and analysis of control systems. When designing and optimizing any control system, the structure and parameters of the controller are primarily dependent on the dynamic behaviour of a controlled plant. The choice of whether a different law of control is determined by the dynamic properties of a controlled plant. The choice of a law of control is determined by the dynamic properties of a controlled plant. In automation systems, developers use: classical PI controllers, PID controllers; adaptive controllers [3, 9]; controllers with fuzzy logic [14]; controllers with fractional derivatives [10]; intelligent controllers [8]; controllers based on neural networks and many other types of controllers. In their research, experts compare the operation of control systems with different types of controllers and draw conclusions about the quality of management. In the study of control systems with different types of controllers unchanged in the system there is a controlled plant, which characterizes the dynamic behaviour of the technological apparatus and formalized in the form of differential equations controlled plant. Thus, an adequate mathematical model of a controlled plant is the basis for the synthesis and analysis of a qualitative control system.

The purpose of the publication is to develop a mathematical model of the heat-mass exchange process for a steam humidifier in the state space, which will allow the analysis of dynamic characteristics of steam generator of industrial air conditioners. An additional requirement is the convenience of using the resulting model in the MatLAB environment.

\section{Dynamical model of steam humidifier}

When developing a mathematical model of a steam humidifier, the model [13] was used as the base model, where the humidification chamber without a steam generator is analysed. In [13], the differential equation of the humidifier chamber material balance is considered in characteristic of relative humidity, which is linearized. Relative humidity is determined by a significant nonlinear dependence on the temperature of air [2]. As a consequence, the temperature range of the use of the linear model is small. Therefore, the material balance equations of the steam humidification chamber will be considered in characteristic of the air moisture content.

The following simplifications were made during the development of a dynamic model of a steam humidifier: heat exchange with the environment is absent, since the thermal losses of modern heaters do not exceed 5\%; the model contains two main dynamic elements with lumped parameters (air space humidifying chamber and steam generator with water); the physical properties of the material flows and the heat transfer surface are brought to the averaged values of the working range. The calculation scheme of the steam humidifier is shown in Fig. 1. 


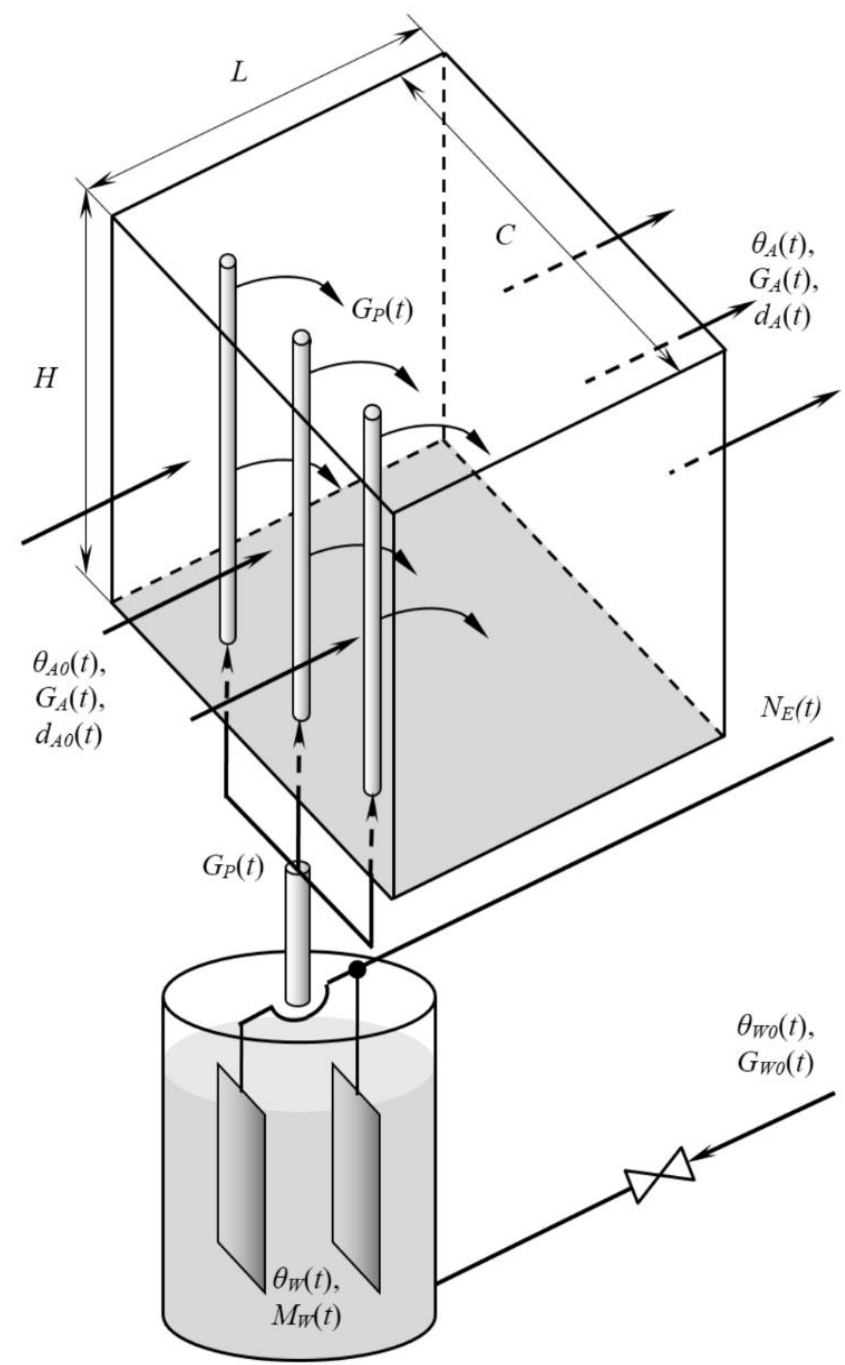

Fig. 1. Schematic diagram for simulation: $\theta_{A 0}(t), d_{A 0}(t), G_{A}(t)$ temperature, moisture and input air flow; $\theta_{A}(t), d_{A}(t)$ temperature, moisture output air; $G_{P}(t)$ steam mass flow; $N_{E}(t)$ input electric power; $\theta_{W 0}(t)$, $G_{W 0}(t)$ feed water temperature and flow; $\theta_{W}, M_{W}$ temperature and mass of water in the steam generator

In the air space of the humidifying chamber with volume $V_{A}=H \times L \times C$ there is air with temperature $\theta_{A 0}(t)$ and moisture content $d_{A 0}(t)$, air flow $G_{A}(t)$. A steam with a mass flow $G_{P}(t)$ of is fed through the steam pipeline to the humidifying chamber. The steam pipeline is connected to the steam generator. The steam generator contains water, the level of which is automatically maintained by the stabilization system of the level by means of feed water with temperature $\theta_{W 0}(t)$ and flow $G_{W 0}(t)$. In the steam generator there are electrodes through which the electric current passes by the power $N_{E}(t)$, at the expense of which the steam is generated. The pair is assimilated in the air, moisturizing it to the output parameters of the air mixture $\theta_{A}(t)$, $d_{A}(t)$. Let's consider the heat and material balance for the air mixture of the humidifying chamber and the steam generator.

The heat balance for the air mixture of the humidifying chamber is:

$$
\begin{aligned}
G_{A}\left[c_{A}\left(\theta_{A 0}-\theta_{A}\right)+\frac{r}{1000}\left(d_{A 0}-d_{A}\right)\right] & + \\
& +r G_{P}=c_{A} M_{A} \frac{d \theta_{A}}{d t},
\end{aligned}
$$

where $c_{A}$ is heat capacity of the air mixture; $r$ is heat of vaporization; $M_{A}$ is mass of moist air in volume $V_{A}$. Consider the material balance for airspace of the humidification chamber. The moisture content accumulated in the humidifier air space is defined as the difference between the mass input and output pairs

$$
\frac{G_{A}}{1000}\left(d_{A 0}-d_{A}\right)+G_{P}=V_{A} \frac{d \rho_{A}}{d t} .
$$

The heat and material balance for the steam generator are represented by the corresponding equations:

$$
\begin{gathered}
G_{W} c_{W} \theta_{W 0}+N_{E}-r G_{P}=c_{W} \frac{d M_{W} \theta_{W}}{d t} \\
G_{W}-G_{P}=\frac{d M_{W}}{d t}
\end{gathered}
$$

where $\theta_{W 0}$ is temperature of feed water; $\theta_{W}$ is water temperature in the steam generator (in operating mode $\theta_{W}=100^{\circ} \mathrm{C}$ ); $G_{P}, G_{W}$ is mass flows of steam and water; $c_{W}$ is heat capacity of water; $N_{E}$ is power of the steam generator; $M_{W}$ is mass of water in the steam generator. Equations (1) - (4) represent a dynamic model of heat-mass exchange for the steam humidifier of an air conditioner:

$$
\left\{\begin{array}{c}
G_{A}\left[c_{A}\left(\theta_{A 0}-\theta_{A}\right)+\frac{r}{1000}\left(d_{A 0}-d_{A}\right)\right]+ \\
+r G_{P}=c_{A} M_{A} \frac{d \theta_{A}}{d t} \\
\frac{G_{A}}{1000}\left(d_{A 0}-d_{A}\right)+G_{P}=V_{A} \frac{d \rho_{A}}{d t} \\
G_{W} c_{W} \theta_{W 0}+N_{E}-r G_{P}=c_{W} \frac{d M_{W} \theta_{W}}{d t} \\
G_{W}-G_{P}=\frac{d M_{W}}{d t}
\end{array}\right.
$$

The design of the steam generator includes a system for stabilizing the water level. For these reasons $\frac{d M_{W}}{d t} \approx 0$ and the differential equation (4) becomes algebraic $G_{W}-G_{P} \approx 0$. Also, let's take into account the constant temperature of water in the steam generator $\theta_{W} \approx 100^{\circ} \mathrm{C}$, from where for equation (3) $\frac{d M_{W} \theta_{W}}{d t} \approx 0$, from which it is easy to determine $G_{P}$ :

$$
G_{P}=\frac{1}{r-c_{W} \theta_{W 0}} N_{E}
$$

Thus, the system of equations (5) is simplified. After grouping similar terms for (1), (2) with regard to (6) and $G_{A} \approx$ const, we obtain a dynamic model of the steam humidifier:

$$
\left\{\begin{array}{l}
T_{A} \frac{d \theta_{A}}{d t}+\theta_{A}=k_{0} \theta_{A 0}+k_{1} d_{A 0}+k_{2} d_{A}+k_{3} N_{E} \\
T_{d} \frac{d d_{A}}{d t}+d_{A}=k_{4} d_{A 0}+k_{5} N_{E}
\end{array}\right.
$$

where $T_{A}=\frac{M_{A}}{G_{A}} ; T_{d}=\frac{\omega V_{A}}{G_{A}} ;$

$$
\begin{gathered}
k_{0}=1 ; k_{1}=\frac{r}{1000 c_{A} G_{A}} ; k_{2}=-k_{1} \\
k_{3}=\frac{r}{c_{A} G_{A}\left(r-c_{W} \theta_{W 0}\right)} ; k_{4}=1 ; k_{5}=\frac{1000}{r-c_{W} \theta_{W 0}}
\end{gathered}
$$

The mathematical model (7) is representable in the states space:

$$
\mathbf{X}^{\prime}=\mathbf{A X}+\mathbf{B} \mathbf{U}
$$


where

$\mathbf{X}=\left[\begin{array}{l}\theta_{A} \\ d_{A}\end{array}\right] ; \mathbf{A}=\left[\begin{array}{cc}-\frac{1}{T_{A}} & -\frac{k_{2}}{T_{A}} \\ 0 & -\frac{1}{T_{d}}\end{array}\right] ; \mathbf{B}=\left[\begin{array}{ccc}\frac{k_{0}}{T_{A}} & \frac{k_{1}}{T_{A}} & \frac{k_{3}}{T_{A}} \\ 0 & \frac{k_{4}}{T_{d}} & \frac{k_{5}}{T_{d}}\end{array}\right] ; \mathbf{U}=\left[\begin{array}{c}\theta_{A 0} \\ d_{A 0} \\ N_{E}\end{array}\right]$

Applying the Laplace transform to the system (7), we obtain:

$$
\begin{gathered}
d_{A}=\frac{1}{T_{d} p+1}\left[k_{4} d_{A 0}+k_{5} N_{E}\right] \\
\theta_{A}=\frac{1}{a_{2} p^{2}+a_{1} p+1}\left[\left(b_{1} p+b_{0}\right) \theta_{A 0}+\right. \\
\left.+\left(b_{3} p+b_{2}\right) d_{A 0}+\left(b_{5} p+b_{4}\right) N_{E}\right]
\end{gathered}
$$

where $\quad a_{1}=T_{A}+T_{d} ; \quad a_{2}=T_{A} T_{d} ; \quad b_{0}=k_{0} ; \quad b_{1}=k_{0} T_{d}$; $b_{2}=k_{1}+k_{2} k_{4} ; b_{3}=k_{1} T_{d} ; b_{4}=k_{3}+k_{2} k_{5} ; b_{5}=k_{3} T_{d}$. Using the inverse Laplace transform, one can find the analytic solution (9) and (10) by the channels of control and disturbance.

Thus, a dynamic model of the steam humidifier, which can be represented as one of the equivalent dependences (7), (8), (9) or (10), is obtained.

\section{An example of dynamic mode simulation for a steam humidifier}

Consider the simulation of dynamic processes for the steam humidifying chamber KCKP-20 of the company "VEZA" in the complete set with the steam generator SMU-233 [2]. Tab. 1 shows the thermal physic parameters for the VEZA KCKP-20 steam humidifying chamber.

Table 1. Thermal physic parameters of the VEZA KCKP-20 steam humidifying chamber

\begin{tabular}{|l|c|c|c|}
\hline \multicolumn{1}{|c|}{ Parameter name } & Marking & $\begin{array}{c}\text { Numerical } \\
\text { value }\end{array}$ & Dimension \\
\hline $\begin{array}{l}\text { Dimensions of the water } \\
\text { heater }\end{array}$ & $H \times L \times C$ & $1 \times 1.4 \times 1.9$ & $\mathrm{~m}$ \\
\hline Flow of air mixture & $G_{A}$ & 6.7 & $\mathrm{~kg} / \mathrm{sec}$ \\
\hline Power of the steam humidifier & $N_{E}$ & 16000 & Watt \\
\hline Moist air density & $\rho_{A}$ & 1.2 & $\mathrm{~kg} / \mathrm{m}^{3}$ \\
\hline Dry air density & $\omega$ & 1.2 & $\mathrm{~kg} / \mathrm{m}^{3}$ \\
\hline Air heat capacity & $c_{A}$ & 1010 & $\mathrm{~J} /\left(\mathrm{kg} \cdot{ }^{\circ} \mathrm{C}\right)$ \\
\hline Water heat capacity & $c_{W}$ & 4185 & $\mathrm{~J} /\left(\mathrm{kg} \cdot{ }^{\circ} \mathrm{C}\right)$ \\
\hline Heat of vaporization & $r$ & 2256000 & $\mathrm{~J} / \mathrm{kg}$ \\
\hline Input air temperature & $\theta_{A 0}$ & 20 & ${ }^{\circ} \mathrm{C}$ \\
\hline Output air temperature & $\theta_{A}$ & 20 & ${ }^{\circ} \mathrm{C}$ \\
\hline $\begin{array}{l}\text { Input water temperature } \\
\text { for steam generator }\end{array}$ & $\theta_{W 0}$ & 20 & ${ }^{\circ} \mathrm{C}$ \\
\hline Input moisture content of air & $d_{A 0}$ & 2 & $\mathrm{~g} / \mathrm{kg}$ \\
\hline $\begin{array}{l}\text { Output moisture content } \\
\text { of air }\end{array}$ & $d_{A}$ & 6 & $\mathrm{~g} / \mathrm{kg}$ \\
\hline
\end{tabular}

Coefficients for models (8)-(10) of the steam generator were calculated in the MatLAB software environment using the coef SMU233.m program:

$\mathrm{H}=1 ; \mathrm{L}=1.4 ; \mathrm{C}=1.9 ;$

$\mathrm{Va}=\mathrm{H} * \mathrm{~L} * \mathrm{C} ;$

$\mathrm{Ga}=0.43$;

$\mathrm{pa}=1.2$;

$\mathrm{w}=1.2$;

$\mathrm{ca}=1010$

$\mathrm{CW}=4182$;

$r=2256000$

TetA $0=20$

Tet $\mathrm{A}=20$;

Tetw $0=20$;

da $0=2$;

$\mathrm{da}=6$;

$\mathrm{Ta}=\mathrm{pa} * \mathrm{Va} / \mathrm{Ga}$
$\mathrm{Td}=\mathrm{w} * \mathrm{Va} / \mathrm{Ga}$;

$\mathrm{k} 0=1$;

$\mathrm{k} 1=\mathrm{r} /\left(1000{ }^{*} \mathrm{Ca}{ }^{*} \mathrm{Ga}\right) ;$

$\mathrm{k} 2=-\mathrm{k} 1$

$\mathrm{k} 3=\mathrm{r} /(\mathrm{ca} * \mathrm{Ga} *(\mathrm{r}-\mathrm{CW} *$ TetW0 $))$;

$\mathrm{k} 4=-1$;

$\mathrm{k} 5=1000 /(\mathrm{r}-\mathrm{CW} * \mathrm{TetW} 0)$;

$\mathrm{A}=[-1 / \mathrm{Ta},-\mathrm{k} 2 / \mathrm{Ta} ; 0,-1 / \mathrm{Td}]$;

$\mathrm{B}=[\mathrm{k} 0 / \mathrm{Ta}, \mathrm{k} 1 / \mathrm{Ta}, \mathrm{k} 3 / \mathrm{Ta} ; 0, \mathrm{k} 4 / \mathrm{Td}, \mathrm{k} 5 / \mathrm{Td}]$;

$\mathrm{a} 1=\mathrm{Ta}+\mathrm{Td}$;

$\mathrm{a} 2=\mathrm{Ta} * \mathrm{Td}$;

$\mathrm{b} 0=\mathrm{k} 0$;

$\mathrm{b} 1=\mathrm{k} 0 * \mathrm{Td}$;

$\mathrm{b} 2=\mathrm{k} 1+\mathrm{k} 2 * \mathrm{k} 4$;

$\mathrm{b} 3=\mathrm{k} 1 * \mathrm{Td}$

$\mathrm{b} 4=\mathrm{k} 3+\mathrm{k} 2 * \mathrm{k} 5$

$\mathrm{b} 5=\mathrm{k} 3 * \mathrm{Td}$;

The calculated coefficients are used in models (8)-(10):

$T_{A}=T_{d}=0.4788$;

$k_{0}=1 ; k_{1}=0.335$;

$k_{2}=-0.335 ; k_{3}=1.5423 \cdot 10^{-4}$;

$k_{4}=1 ; k_{5}=4.6033 \cdot 10^{-4}$;

$a_{1}=0.9576 ; a_{2}=0.2292$;

$b_{0}=1 ; b_{1}=0.4788 ; b_{2}=0 ; b_{3}=0.16$;

$b_{4}=0 ; b_{5}=7.385 \cdot 10^{-5}$.

$$
\begin{gathered}
{\left[\begin{array}{l}
\theta_{A}^{\prime} \\
d_{A}^{\prime}
\end{array}\right]=\left[\begin{array}{cc}
-2.0886 & -0.6998 \\
0 & -2.0886
\end{array}\right]\left[\begin{array}{l}
\theta_{A} \\
d_{A}
\end{array}\right]+} \\
+\left[\begin{array}{ccc}
2.0886 & 0.6998 & 3.2212 \cdot 10^{-4} \\
0 & 2.0886 & 9.6142 \cdot 10^{-4}
\end{array}\right]\left[\begin{array}{c}
\theta_{A 0} \\
d_{A 0} \\
N_{E}
\end{array}\right] \\
d_{A}=\frac{1}{0.4788 p+1}\left[d_{A 0}+4.6033 \cdot 10^{-4} N_{E}\right] \\
\theta_{A}=\frac{1}{0.2292 p^{2}+0.9576 p+1}\left[(0.4788 p+1) \theta_{A 0}+\right. \\
\left.+0.16 p d_{A 0}+7.385 \cdot 10^{-5} p N_{E}\right]
\end{gathered}
$$

Simulation modelling of the dynamic mode for the steam humidifier was carried out in the Simulink MatLAB environment using the State Space functional block. The simulation results of transients along the control channel are presented in Fig. 2. The results of the simulation of transients along disturbance channels are shown in Fig. 3.

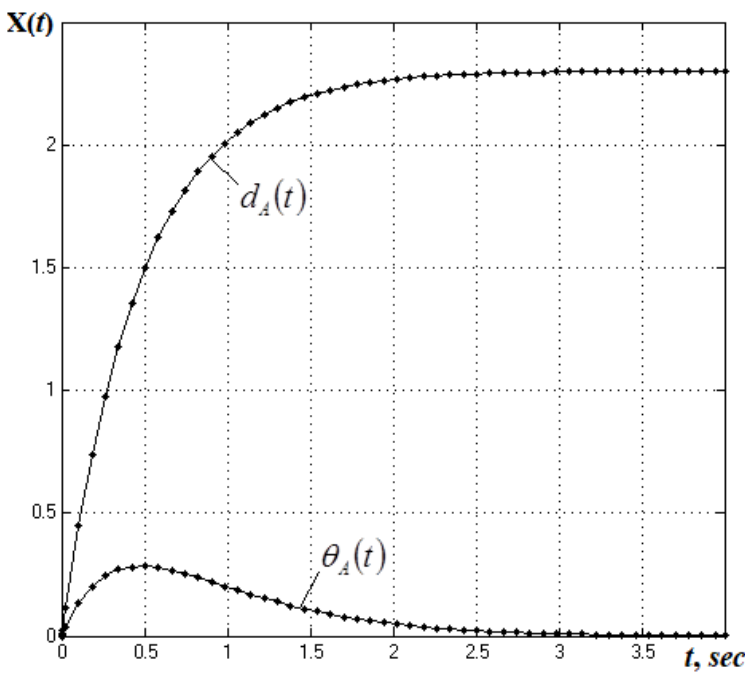

Fig. 2. Graphs of the transient processes for the control channel $N_{E} \rightarrow \mathbf{X}(t)$ 


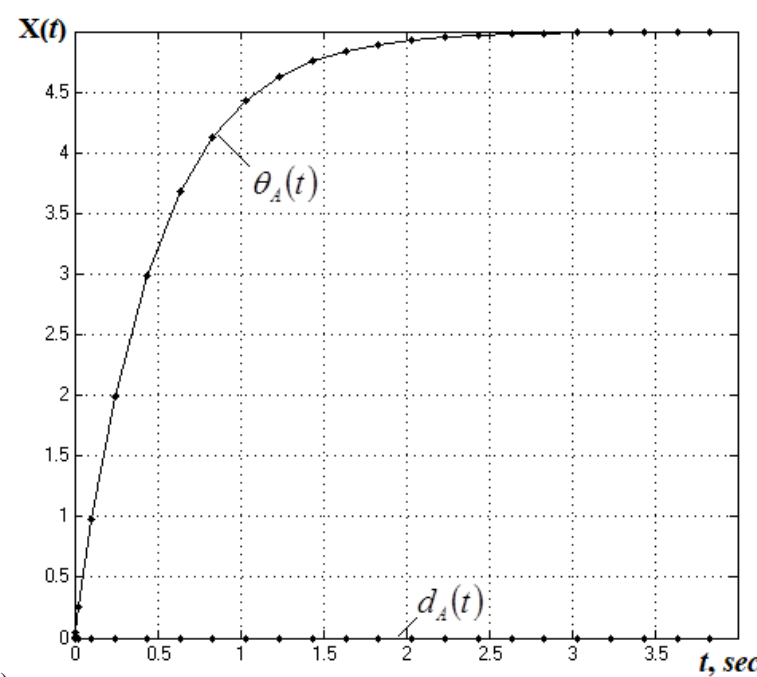

a)

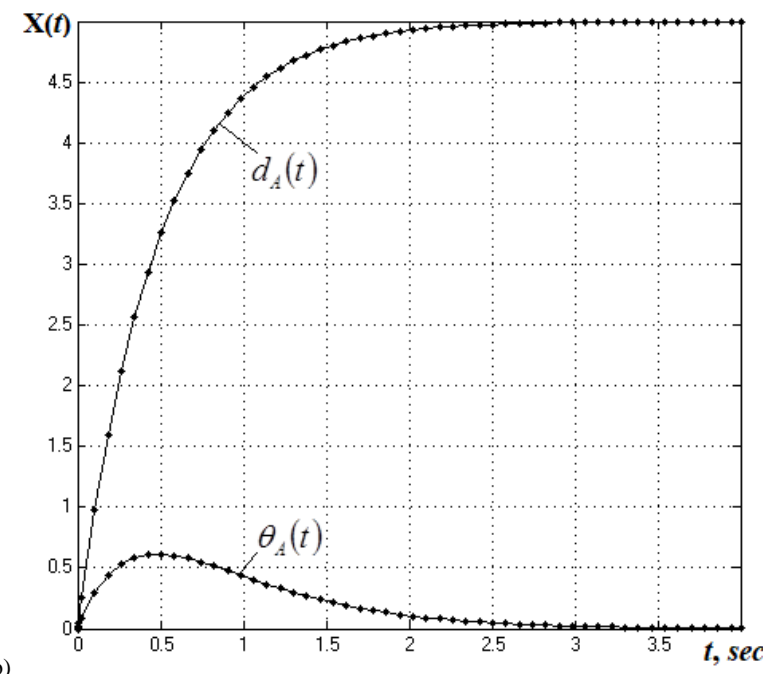

b)

Fig. 3. Graphs of the transient processes for the perturbation channels. a) $\theta_{A 0}(t) \rightarrow \mathbf{X}(t)$; b) $d_{A 0}(t) \rightarrow \mathbf{X}(t)$

The results of the simulation can be summarized as follows. The inertia of the regulation and perturbation channels is insignificant compared to the inertia of the temperature and moisture sensors. For these reasons, when designing the system for controlling steam humidifier, it is necessary to take into account the inertial properties of the temperature and moisture sensors.

\section{Conclusions}

In article was proposed maths model of heat-mass exchange for a steam humidifier. The proposed dynamic model takes into account mass transfer with moisture content. Existing models consider a relative humidity, so the proposed model allows us to demarcate between the nonlinear effect of temperature on air humidity. Using the new model for the synthesis of an air conditioning control system will allow to divide out between the effect of temperature at humidity.

The steam humidifier model to is offer from equivalent dependencies in: a) the differential equations form (7); b) the state space (8); c) the transfer functions form (9), (10). The mathematical dependence choice is determined by the control system synthesis method.
The proposed dynamic model is recommended to be used in the support and decision-making system at the middle level of enterprise management [7]. This will integrate the air conditioning control system into the enterprise management system. Such an approach will allow the company to transfer to a qualitatively new level of management and allow the efficient use of energy resources.

\section{References}

[1] Belova E.M.: Central Air Conditioning Systems in Buildings. Euroclimate, Moscow 2006

[2] Conditioners Central KCKP. Catalog Equipment VEZA. 2019 http://www.veza.ru/docs/konditsionery-tsentralnye-ktskp

[3] Deacha P.: Multiobjective Multipath Adaptive Tabu Search for Optimal PID Controller Design. International Journal of Intelligent Systems and Applications 7, 2015, 51-58.

[4] Golinko I.M. The dynamic model of heat-mass exchange for water cooling of industrial air conditioning. Science and Technology NTUU KPI 6, 2014, 27-34.

[5] Golinko I.M., Kubrak N.A.: Modeling and Optimization of Control Systems. Ruta, Kamyanets-Podilskii 2012.

[6] Golinko I.M., Ladanuk A.P., Koshelieva L.D.: Dynamic Model of the Calorifier Heat Mode. Information Technology and Computer Engineering 3, 2009, 59-63.

[7] Pankratova N., Bidyuk P., Golinko I.: Decision Support System for Microclimate Control at Large Industrial Enterprises. Proceedings of The Third International Workshop on Computer Modeling and Intelligent Systems (CMIS-2020), 489-498.

[8] Lakshmi K.V., Srinivas P., Ramesh C.: Comparative Analysis of ANN based Intelligent Controllers for Three Tank System. International Journal of Intelligent Systems and Applications 8, 2016, 34-41.

[9] Poonam S., Agarwal S.K., Narendra K.: Advanced Adaptive Particle Swarm Optimization based SVC Controller for Power System Stability. International Journal of Intelligent Systems and Applications 7, 2014, 101-110.

[10] Soukkou A., Belhour M.C., Leulmi S.: Review, Design, Optimization and Stability Analysis of Fractional-Order PID Controller. International Journal of Intelligent Systems and Applications 8, 2016, 73-96.

[11] Tkachov V., Gruhler G., Zaslavski A., Bublikov A., Protsenko S.: Development of the algorithm for the automated synchronization of energy consumption by electric heaters under condition of limited energy resource. Eastern European Journal of Enterprise Technologies 8, 2018, 51-61.

[12] Vychuzhanin V.V.: Mathematical models of non-stationary modes of air processing in the central ACS. Bulletin of the Odessa National Maritime University $23,2007,172-185$.

[13] Vychuzhanin V.V.: Scientific and technical bases of operation of ship's central systems of comfortable air conditioning. Dissertation of technical doctor sciences, 2009.

[14] Yazdanpanah A., Piltan F., Roshanzamir A.: Design PID Baseline Fuzzy Tuning Proportional Derivative Coefficient Nonlinear Controller with Application to Continuum Robot. International Journal of Intelligent Systems and Applications 6, 2014, 90-100.

\section{Ph.D. Igor Golinko}

e-mail: conis@ukr.net

Associate professor of the sub-department of Automation Heat-and-Power Engineering processe of Heat-and-Power Engineering department, National Technical University of Ukraine "Igor Sikorsky Kyiv Polytechnic Institute", Kyiv, Ukraine. Author of over 100 scientific papers. Engaged in scientific mathematical simulation of technical and technological processes, computer techniques and computer technologies, programming.

http://orcid.org/0000-0002-7640-4760

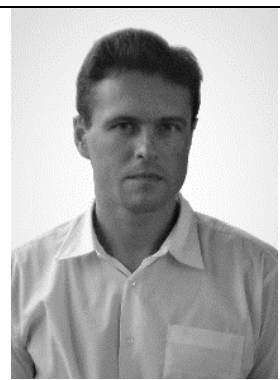

Prof. D.Sc.(Technical) Volodymyr Drevetskiy e-mail: Westra@rv.uar.net

Vice President of Engineering Academy of Ukraine, Head of Automation, electrical engineering and computer integrated technologies Department, National University of Water Management and Nature Resources Use, Rivne, Ukraine.

The main scientific direction - developmen of methods and devices for continuous automatic monitoring of the physical and mechanical parameters of Newtonian and non-Newtonian fluids, as well as the quality of oil products. Author of over 200 scientific papers, including 51 patents, most of which are implemented in production.

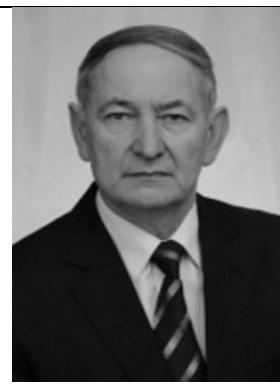

http://orcid.org/0000-0001-8999-2226

otrzymano/received: 21.12 .2019 